\title{
The joy of seeing Christ: A thematic study of joy in the Gospel of John
}

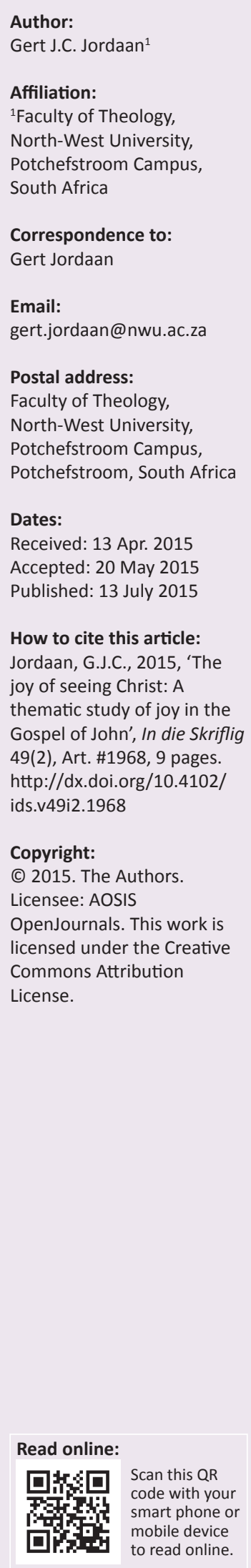

An investigation of the recurring references to joy in the fourth Gospel brings to light that joy is developed in the Gospel as a distinct theme. This theme is developed in typical Johannine style within a spiral-like pattern, with its climax in the joy of seeing Jesus as the risen Lord. Furthermore, starting with Abraham in the Old Testament and climaxing in Jesus' appearance after his resurrection, joy in the fourth Gospel is evolved within the broad theological framework of God's covenant and his kingdom.

Blydskap om Christus te sien: 'n Tematiese studie van blydskap in die Johannes-Evangelie. 'n Ondersoek na die herhaalde verwysings na blydskap in die vierde Evangelie bring aan die lig dat blydskap in hierdie Evangelie tot 'n selfstandige tema uitgebou word. Die tema is volgens die tipiese spiraalpatroon van Johannes se gedagtegang gerangskik, met sy klimaks in die blydskap daarvan om Jesus as die opgestane Here te sien. Binne hierdie patroon word die blydskaptema vanaf Abraham in die Ou Testament tot by Jesus se verskyning ná sy opstanding openbaringshistories ontvou en binne die breë raamwerk van die verbond en die koninkryk van God ontwikkel.

\section{Introduction and problem statement}

A very distinct structural trait of the fourth Gospel is that certain words and concepts are often repeated. Some of these repetitions are regarded by scholars as markers of themes within the Gospel, which led to a number of thematic studies, such as Spirit, life and truth in John (e.g. Coetzee 1990; Holwerda 1959; Lincoln 2000). A recurring concept in the Gospel that, as far as I could detect, has not yet been studied as a possible theme, is that of joy. There were studies of Gulin (1936) and Keenan (1963) which focused on a theological definition of John's concept of joy. The only other contribution about joy in the fourth Gospel was a summary of references that was compiled and published on the Johannine literature web by Just (2012). But the repetition of joy in the fourth Gospel and the significance thereof seems to have been neglected thus far.

Whether a repeated concept such as joy in John comprises to a distinct theme or only marks a motif is not easy to tell at first sight. Both themes and motifs are marked by a frequently repeated concept. Scholars often use theme and motif as mere synonyms (Du Rand 2005:23; Lincoln 2000:4). Yet they should be regarded as distinct (Abbott 2002). Normally they can be distinguished on the basis that a theme is a repeated concept which is developed in itself whereas a motif, although repeated, is not developed in itself but only contributes to the emotional, moral or cognitive development of the argument or narrative (cf. Freedman 1971:123). However, in recent narrative theory motifs simply tend to be viewed as concrete and themes as abstract (Abbott 2002:237). The hypothesis of this article is that since joy is an abstract concept that is repeated and developed throughout the fourth Gospel, it should be regarded not as a motif but as a distinct theme.

For the study of a specific theme or motif in the text a method is required that will bring forward the mutual coherence of references in the book, as well as the nature of its coherence. For this purpose the revelation-historical method of Coetzee (1995) is followed. This method is closely related to the approach of biblical theology (cf. Balla 1997; Childs 1993). Its purpose is to come to a total description of the development of a theme in a book as part of the book's structure and message and as part of the general revelation of Scripture (Coetzee 1995:9).

Accordingly the study begins by making a survey of the occurrence of joy words within the book. The next step is to identify any logical or theological coherence between these recurring words. This is done by making a cursory exegetical study (historically and/or grammatically) of each 
joy passage. Thereupon the way in which each joy passage fits into the book's thought-structure is investigated. Finally the contribution of the joy motif to the entire message of the book is described.

\section{The occurrence of joy in the fourth Gospel}

The rather restricted vocabulary of John is well illustrated by his use of Greek words referring to joy. From the eight words employed in the New Testament within the semantic

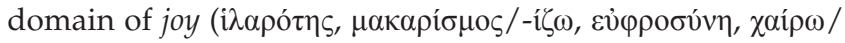

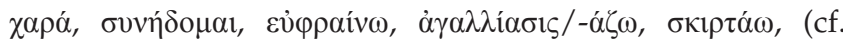

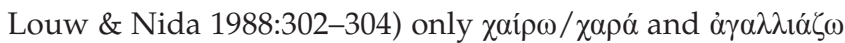
are used in John. These words are found at the following places: ${ }^{1}$

- John 3:29 - the joy of the Baptist.

- John 4:36 - the joy of the reaper and the sower.

- John 8:56 - the joy of Abraham.

- John 11:15 - Jesus' joy before raising Lazarus.

- John 14:28 - the disciples' joy because Jesus is going to the Father.

- John 15:11 - the disciples' joy at the teaching of Jesus.

- John 16:20-24 - the disciples' joy at the return of Jesus.

- John 17:13 - the disciples' joy at Jesus' intercession.

- John 20:20 - the disciples' joy when they saw the risen Jesus.

On first sight the following matters regarding these nine passages are observed:

- References to joy are more or less evenly spread throughout the book.

- In four of the nine passages joy is referred to as a completed joy.

- The first four references to joy are about the joy of specific individuals. The remaining five instances involve the joy of the disciples or the believers in general.

- All the references to joy, with the exception of the first $\left(3: 29^{2}\right)$ and the last $(20: 20)$ passage, are part of words spoken by Jesus.

With these observations in mind, we can now proceed to the cursory exegetical survey of each of the nine joy passages.

\section{Joy in the separate passages of John John 3:29}

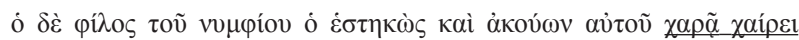

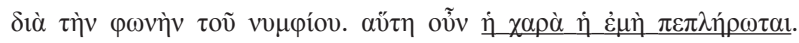
[New International Version (NIV): The friend who attends the bridegroom waits and listens for him, and is full of joy when he hears the bridegroom's voice. That joy is mine, and it is now complete.]

\footnotetext{
1.The complete Greek text (from the UBS 4 corr edition) and NIV translation are provided with thediscussion of each passage in the section 'Joy in the separate passages of John'.

2.References where only the chapter and verse are stated, come from the Gospel of John.
}

By these words John the Baptist made it clear that he himself was not the messiah but only the preparer of the way (3:28). The words contain a metaphor ${ }^{3}$ in which Jesus is compared to a bridegroom (vó $\mu \varphi \imath \varsigma)$ and John to his groomsman or 'best

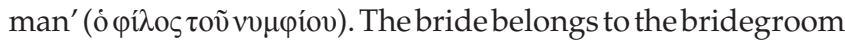
and not to the groomsman (3:29). The metaphor of a bride and bridegroom reminds of Old Testament passages such as Jeremiah 2:2 and Ezekiel 16:8, where Israel is portrayed as the bride of the Lord. It is also used in New Testament passages such as 2 Corinthians 11:2; Ephesians 5:25-27 and Revelation 21:2; 22:17 (cf. Bruce 1992:95; Schwank 1998:118). However, in John 3:29 the focus is not on the bride, but on the relation between the bridegroom and his groomsman.

To 1st century Judeans the relation between a bridegroom and his groomsman was probably well known. From 1st century rabbinic literature a picture can be drawn of what was expected of a groomsman in Judean society (cf. Keener 2003:579-580; King \& Stager 2001:55). Since the groomsman (Aram. shoshbin) had a very important task for the wedding, he was chosen with much forethought by the bridegroom, and would normally be a close 'friend of the bridegroom'. The shoshbin seems to have been responsible for all the preparations leading up to the wedding, almost as a wedding planner or organiser for the bridegroom (cf. also Bernard 1948:1.131; Bultmann 1971:173; Ridderbos 1987). Eventually he, together with the shoshbin from the bride's side of the family, functioned as witnesses to the wedding (cf. Barrett 1955:185; Keener 2003:579).

By this metaphor the Baptist explains that he was the one who prepared the way for Jesus as the bridegroom. The greatest achievement for the groomsman would be that on the wedding day all the guests would be ready, waiting for the bridegroom to make his appearance. And when on that day he hears the voice of the groom, joy springs up in him because he knows that the groom has arrived and that his work as groomsman is done (Wallace 2004:63). Likewise the Baptist on hearing the voice of Jesus is overjoyed, realising that his task as 'groomsman' is coming to an end. To express his overjoy, he uses the emphatic infinitive absolute: $\chi \alpha \rho \tilde{\alpha}$

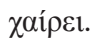

In John 3:26 the Baptist receives report that 'everyone is going to Jesus'. To hear these reports was in fact the very last 'groomsman' task of the Baptist, for thereby he acted as witness that the bride and the groom were finally coming together. So his mission as preparer of the way was fulfilled

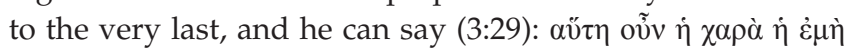
$\pi \varepsilon \pi \lambda \eta \dot{\rho} \omega \tau \alpha$ - this joy of mine is now complete. The perfect participle emphasises the fact that the present joyous state of affairs results from a previous event, the event in this case being that the bride and groom are actually coming together.

As preparer of the way for the Messiah the Baptist was the prophet who stood on the threshold between the old and

3.According to Barrett (1955:185) John $3: 29$ should be regarded as a short parable. However, Köstenberger (2002:87) clearly shows it to be a metaphor. 
the new dispensation (Mt 11:10-14; Mk 1:2; Jn 1:23). He had the privilege not only to prepare the way for the promised Messiah but also to see him coming in the flesh. And in John 3:29 we hear that, now that the Messiah has come, all eyes are drawn away from the prophets and fixed upon Jesus, the Christ. ${ }^{4}$ The prophecies were fulfilled, and the joy of the Baptist had become complete.

Thus the Baptist's joy was complete not in the sense that it has reached its climax but in the sense that he has seen the promises of Scripture becoming reality (Gulin 1936:67). In

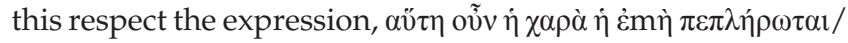
$\pi \varepsilon \pi \lambda \eta \rho \omega \mu \varepsilon \dot{v \eta}$, is linked to expressions that refer to fulfilment of a promise, such as îv $\pi \lambda \eta \rho \omega \theta \tilde{\omega} \sigma v \alpha$ i $\gamma \rho \alpha \varphi \alpha i$ ['so that the

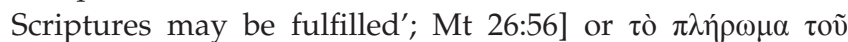

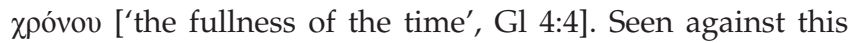
background, the complete joy of the Baptist, the joy of standing on the threshold and finally seeing the promised Messiah appear in the flesh, in fact represented the joy of all the prophets of the Old Testament.

In a nutshell: The Baptist as ultimate prophet of the old dispensation was overjoyed to see the promised Messiah appear.

\section{John 4:36}

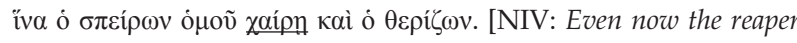
draws his wages, even now he harvests the crop for eternal life, so that the sower and the reaper may be glad together.]

'The sower and the reaper will rejoice together' is part of harvest imagery which Jesus used whilst speaking to his disciples. Generally speaking, the disciples would understand this imagery quite well. In agricultural communities the harvest was always regarded as a joyful event (cf. Ps 126:6; Is 9:2). But something that would seem strange to the disciples was that Jesus said that the reaper's joy will be shared by the sower. Firstly, the sower's work was normally not associated with joy (Ps 126:5, 6); secondly, the sower and the reaper could normally not rejoice together because they did not work together (Van der Watt 2000:100). However, the strangeness of joy being shared by the sower and the reaper is only one of a few metaphoric 'disturbances' or 'incongruencies' in the imagery of John 4:35-36 (cf. Van der Watt 2000:92-101).

The first disturbing element is in verse 35 where Jesus says to his disciples: 'Open your eyes and look at the fields. They are ripe for the harvest'. Yet, as he was speaking it was still four months before the harvest time (cf. 4:35; Keener 2003:624). Obviously he was speaking metaphorically about a harvest. Spoken within the context of the Samaritan conversion (4:1-39), he was probably speaking of the harvest of Samaritan believers (Bruce 1992:114; Neyrey 2007:98). That this was indeed what Jesus had in mind, is confirmed by the second incongruence, in verse 36, where Jesus says that the

4.A similar idea is found in Colossians 2:17 where Paul writes about the Old Testament ceremonies: 'These are a shadow of the things that were to come; the reality, however, is found in Christ. harvest brings a 'crop for eternal life'. The 'crop for eternal life' refers to those who believe and come to faith (cf. 3:16; 3:36; 20:31; Van der Watt 2000:96).

Jesus indeed means the sower and reaper to be two different persons or groups. In verse $37 \mathrm{He}$ says: 'It is one who sows and another who reaps'. How can their shared joy be explained? Neither the immediate context nor socio-historical evidence provides an answer. Bultmann attempts to explain it within his framework of realised eschatology. According to him the tension between present and future is resolved in the eschatological time so that "in earthly time the "coming" of the Revealer and his "going away" are separate events, in eschatological time they are contemporaneous' (Bultmann 1971:198). Instead of a philosophical approach, however, this article calls for a revelation-historical approach, which requires that biblical passages should be understood within the context of the entire Scripture.

The only other passages that speak of sowing and harvesting at the same time are Leviticus 26:5 and Amos 9:13. John 4:36 probably alludes to the prophecy of Amos 9:13: 'The days will come, says the Lord, when the plowman shall overtake the reaper, and the treader of grapes him that sows the seed.' These last words refer to the days when the Lord will restore the fallen house of David, as is evident from Amos 9:11. They will be days of joy and abundance (Am 9:14), the days of the coming Messiah (cf. Bernard 1948:158; Hendriksen 1953:174). The revelation-historical sense of the allusion in John 4:36 is probably that the harvest amongst the Samaritans should be seen as the first fruits of the restoration of the royal house of David. The sower is Jesus and the disciples are witnesses of the incoming harvest. Thus the disciples are reapers who share the joy of the sower, Jesus. The disciples' greatest joy is that in the harvest they see that the messianic age has indeed broken through.

In a nutshell: The disciples rejoiced because they saw the first fruits of Jesus' preaching in this world, realising that in him the messianic age had indeed arrived.

\section{John 8:56}

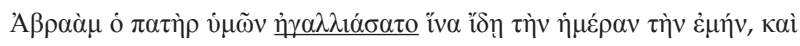

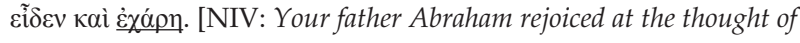
seeing my day; he saw it and was glad.]

These words Jesus spoke towards the end of his argument with the Jews (8:12-59). The real matter in dispute was the glory ( $\delta$ ó $\xi \alpha$ ) of Jesus (8:50, 54; cf. Bouma 1974:229). The Jews did not see or acknowledge Jesus' glory. They rejected him as one who had only himself as witness of his own glory $(8: 13,45)$ and regarded the claim that he was greater than Abraham as outrageous (8:53). But Jesus made it clear that he did not glorify himself; he was glorified by the Father (v. 54). And speaking of Abraham, Abraham himself gave witness to the glory of Jesus. Verse 56: 'Your father Abraham rejoiced at the thought of seeing my day; he saw it and was glad.' 
When did Abraham see the day of Christ? Commentators have different opinions on this matter. Some of them refer to a Jewish tradition that Abraham saw the whole history of his descendants in the vision of Genesis 15 (cf. Brown 1966:360; Hunter 1965:94). Bernard explains the verse as joy experienced by Abraham after his death. He bases his view

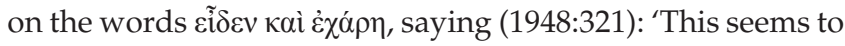
say that Abraham in the other world was joyfully conscious of Christ's appearance in the flesh. ${ }^{5}$ Although not connecting it to a Jewish tradition of some kind, De Lange (2008:77) explains Abraham's seeing of Jesus before his time in terms of the pre-existence of Jesus. There are various other rabbinic traditions that could be connected to this verse. But none of these are seriously considered by scholars as the background of John 8:56 (cf. Keener 2003:767).

A number of scholars (e.g. Bultmann 1971:326; Ridderbos 1987:471) more or less agree with the view of Origen that Abraham exulted in the anticipation of seeing the day of Christ. ${ }^{6}$ Thus Abraham's joy was the joy of knowing that the promised Messiah will come one day. Carson (1971:357) takes this view a little further. Linking up to another Jewish tradition which says that Abraham rejoiced greatly at the birth of Isaac, he suggests that Abraham rejoiced because in the birth of Isaac he saw the first proof of the promised day when the Christ would come (cf. also Ridderbos 1987:371).

Whether encouraged by the birth of Isaac or not, Abraham prophetically saw the future day of Christ as promised by God, and rejoiced in it. When speaking of Abraham and of God's promise of the Messiah, a new aspect comes into the picture, that is the covenant of God. When Jesus refers to Abraham's joy over the promised Messiah, he is taking us back to the beginning of God's covenant of grace, which he made with Abraham, and which was fulfilled in the coming of Jesus as the Christ. Therefore one can say that in this passage the joy about Christ comes from way back in history - when Abraham at the outset of the Lord's covenant was seeing Christ from afar, joyously holding on to God's promise of the coming Messiah.

Thus the argument in John 8:56 seems to be: Abraham's joy was a prophetic witness from the Old Testament that Jesus would indeed be sent by God according to his covenantal promise, and that the glory would indeed belong to Jesus.

In summary: Abraham from the Old Testament (at the outset of the covenant) looked forward with joy to the day when the promised Messiah will appear.

\section{John 11:15}

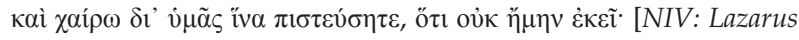
is dead, and for your sake I am glad I was not there, so that you may believe.]

5.Cf. also Haenchen (1980:371), who relates this explanation to a rabbinic exposition of Genesis 17:17.

6.In contrast to Ridderbos, Bultmann understands the day of Christ in terms of a realised eschatology, as briefly discussed in the section: 'John 4:36'.
This is the only passage in John that refers to joy not experienced by the believers but by Jesus himself. Jesus was glad for the sake of the disciples that he was not present at the death of Lazarus. He knew that the death of Lazarus would result in yet another sign that would reveal his glory and prove that he is the Son of God (cf. Haenchen 1980:402; Ridderbos 1987:21). Yet Jesus' joy was not detached from the people around him. He was glad for the sake of the disciples, because he knew that the sign of Lazarus being raised from the dead would make their faith stronger and would bring others to believe (Bernard 1948:379; Bultmann 1971:400).

In a certain sense the joy in John 11:15 links with the joy in John 4:36. In John 4:36 the disciples had to rejoice over the faith of the Samaritans due to Jesus' word preaching. In John 11:15 the joy is about faith that was caused by Jesus' sign preaching.

Therefore the contribution of John 11:15 to the theme of joy in the fourth Gospel is that it portrays Jesus' preaching to be not only a preaching in words but also a preaching in signs or deeds.

\section{John 14:28}

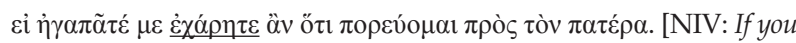
loved me, you would be glad that I am going to the Father.]

John 14:28 is the first of the joy passages in the fourth Gospel that forms part of the so-called farewell discourse of Jesus. A characteristic feature of the farewell discourse is the repetition of themes or motifs. Certain themes and motifs of chapter 14 are taken up again and expanded on in chapters 15 and $16 .^{7}$

Of special importance for the discussion of John 14:28 is the repetition regarding grief and joy $(14: 1,28 ; 16: 5-6,16-33)$. In chapter 14 Jesus says that at his departure the disciples should experience joy (14:28) instead of sadness (14:1). This very same idea is taken up again in chapter 16 and expanded, especially in verses 16-33. In both chapters the passage is introduced by the intriguing statement of Jesus that in a short while you will not see me, but (then in a short while) you will see me' $(14: 19 ; 16: 16)$. In chapter 16 , however, it is expanded by the disciples' enquiry about the statement (16:17-19) and Jesus' answer (16:20-22).

Due to these obvious parallels between John 14:19-28 and 16:16-33, I chose to discuss these passages together in the section 'John 15:11' below. At this point, only a few remarks regarding John 14:28 are called for.

\footnotetext{
7.Obvious repetitions are those about prayer, about the world's ignorance and hate about the Spirit as Paracte and about gief and joy. Due to these repetitions about the Spirit as Paraclete and about grief and joy. Due to these repetition many scholars are convinced that chapters $15-16$ are an interpolation, or at least misplaced. Without entering the debate about such a possible addition, I agree with Ridderbos (1987:132) that the repetitions of chapters 15-16 were deliberate expansions of chapter 14 . Such repetitions are completely in character with the typical spiral pattern in which John organised his narrative.
} 


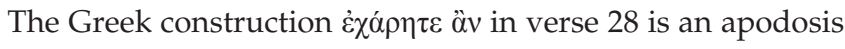

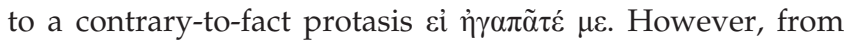
the context it proves that it is not the disciples' love but their joy that is contrary to fact. Since they are sad instead of being glad, Jesus is in fact appealing to their love for him (Hendriksen 1953:288): 'If you really love Me (and I know that you do), you will be glad that I am going to the Father.'

The reason why he appeals to their love is presented in the

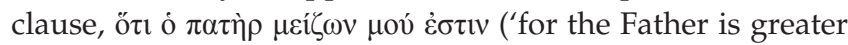
than $\left.I^{\prime}\right)$. The purpose of this clause is not to instruct the disciples on the relation between the Father and the Son, but to explain to them why they should be glad that he is going to the Father. His going to the Father is to their benefit, because 'the Father is greater than I'. In this phrase Jesus explains to the disciples that he was leaving this earth for a greater glory where the Father is. He is speaking of his ascension (Hendriksen 1953:288). Jesus' ascension will be reason to rejoice, because when he returns to the Father in heavenly glory the new dispensation of grace will be a reality (Ridderbos 1987:162).

\section{John 15:11}

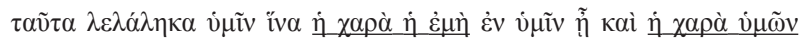
$\underline{\pi \lambda \eta \rho \theta \theta \tilde{\eta}}$. [NIV: I have told you this so that my joy may be in you and that your joy may be complete.]

John 14's teaching about Jesus' continued spiritual union with his disciples after his departure is expanded and enlightened in John 15:1-8 by means of the metaphor of a vine and its branches (Van der Watt 2000:29-31). At the end of this metaphor in John 15:11, Jesus says that he had said these things to his disciples ( $\tau \alpha \tilde{v} \tau \alpha \lambda \varepsilon \lambda \dot{\alpha} \lambda \eta \kappa \alpha \dot{v} \mu \tilde{i} v)$ so that his joy would be in them and their joy would be complete.

Bernard (1948:485) points out that the phrase, $\tau \alpha \tilde{v} \tau \alpha \lambda \varepsilon \varepsilon \lambda \dot{\alpha} \lambda \eta \kappa \alpha$ viñv, recurs no less than seven times in Jesus' farewell discourse and that in each case, $\tau \alpha \tilde{\tau} \tau \alpha$, refers to what has been said in the previous sentences. Therefore he takes $\tau \alpha \tilde{v} \tau \alpha \lambda \varepsilon \lambda \dot{\alpha} \lambda \eta \kappa \alpha \dot{v} \mu \tilde{v}$ in John 15:11 as a reference to loving obedience to the Father in verse 10 (cf. also Barrett 1955:397; Wallace 2004:239). Carson (1991:521) says: 'In his obedience to the Father Jesus experienced pure joy. Those who obey the Father will receive the same joy.'

Although such an interpretation indeed makes a valid point, it does not consider the broader context of 15:11 sufficiently. The entire preceding pericope, including the vine-branches metaphor (15:1-10), and its relation to the corresponding passages in chapter 14 should be taken into account. Only then does it become clear that the joy that Jesus speaks of in 15:11 is related to the union between him and his disciples. The fact of their on-going spiritual union was stated repeatedly in 14:2-3; 15:18-23; it was amplified and explained by means of the vine-and-branches metaphor in 15:1-10; and

8. Since the 4th century this phrase was scrutinised by many theologians in dogmatic controversies about the subordination of the Son to the Father (cf. Schwank 1998:373-374) also in 15:11-17 Jesus explains the practical effects of this union (Brodie 1997:479-483). Seen from this perspective the disciples' joy in John 15:11 is the effect or result of their union with Christ.

The effect or result of this union seems to be that the disciples receive joy from Jesus ('that my joy may be in you'), almost as a commodity ( $\chi \alpha \rho \alpha$ being an abstract noun) or a gift. At least one can say that joy is an aspect of faith that believers receive through their union with Christ. Bultmann (1971:541) subscribes to this idea, saying that Jesus' joy becomes their joy because in their union with him the disciples receive the 'eschatological existence'. Bultmann's idea of the 'eschatological existence' comes from his realised eschatology, defined by him in existentialistic terms (1971:32; cf. also 'John 4:36' above). Thus the disciples' joy would be a here-and-now experience of the eschatological Christ who comes to life in them in a mystical union. In this sense Bultmann understands the words 'your joy will be complete' (Bultmann 1971:541). However, the Johannine teaching of 'Christ in us and us in Christ' does not speak of a mystical union between Christ and his disciples but of loving obedience due to the indwelling of the Spirit. Likewise it does not speak of a mystical joy of Christ that comes to life in the disciples, but a joy of the disciples because they witness the results of their union with Christ in their own lives (Gulin 1936:42-51).

Instead of Bultmann's realised eschatological view, I prefer to follow the explanation of Bouma (1974:98-101) that by the metaphor of the vine and its branches Jesus emphasises a living relationship between him and those who embrace him in faith. As the vine provides life-giving sap to its branches so that they can bear fruit, only because of their union with the vine, likewise the believers (disciples) can only bear fruit as long as through faith they remain in Christ (15:4-8). One of the first fruits of this union is that Christ's loving obedience to the Father comes forward also in their lives. And from this fruit follows a special gift, which consists in the joy of seeing through the eyes of faith that in Christ God is indeed present and that by the Holy Spirit the believers are indeed one with Christ (Brodie 1997:482-483).

From this last explanation follows that by the words 'your joy will be complete', Jesus teaches his disciples that human joy is incomplete without being united with Jesus Christ by faith; also that the joy of union with Christ is incomplete without the fruit of loving obedience towards God (Carson 1991:521).

To summarise: In John 15:11 Jesus speaks of the joy of his disciples, which results from their union with him and which is made complete by the fruit of obedience that they bear.

\section{John 16:20-24}

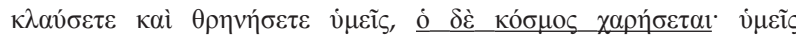

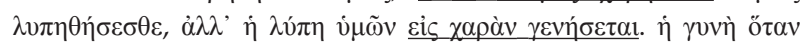

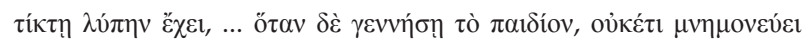




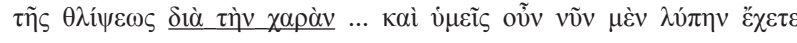

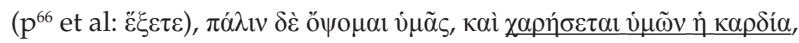

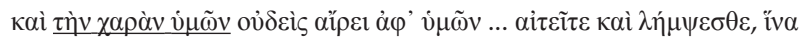

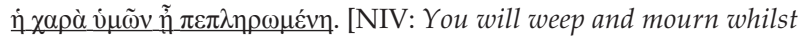
the world rejoices. You will grieve, but your grief will turn to joy. A woman giving birth to a child has pain because her time has come; but when her baby is born she forgets the anguish because of her joy that a child is born into the world. So with you: Now is your time of grief, but I will see you again and you will rejoice, and no one will take away your joy ... Ask and you will receive, and your joy will be complete.]

Based on the relation between John 14 and 15-16 (cf. 'John $11: 15^{\prime}$ above) the pericope John $16: 20-24$ is taken as a repetition and expansion of the theme of grief and joy in $14: 28$. Also the theme of praying in Jesus' name (14:13-14) is reiterated in this pericope. As a matter of fact, in John 16:20-24 the themes of joy and prayer are connected, as is argued below.

In John 16:20-24, as in 14:28, the theme of grief and joy forms part of Jesus' announcement of his death and resurrection (Keener 2003:1043). ${ }^{9}$ For a short while, Jesus says in verse

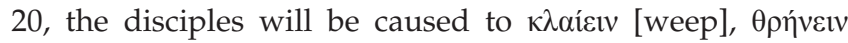
[mourn] and $\lambda v \pi \varepsilon \tilde{v}$ [grieve] - words used almost exclusively in connection with death (cf. Barrett 1955:410). Then, a short while later their grief will turn to joy. This will be when they will see him after his resurrection. This is confirmed by John 20:20, where we read that after his resurrection, 'the disciples were overjoyed when they saw the Lord' (cf. Bruce 1992:323; Carson 1991:543).

Jesus compares the future joy of the disciples to a child-bearing woman whose anguish makes place for overwhelming joy once her child is born (verse 21). This comparison, which is often used in biblical and Jewish writings (e.g. Is 26:17; 66:7-14; Micah 4:9; cf. Keener 2003:1045; Ridderbos 1987:192; Sanders 1968:358) makes it clear that the disciples will be able to endure their grief knowing well that it will soon turn to joy. However, the main reason for the disciples' joy would not merely be because they see their beloved Rabbi again alive. Their joy would spring from the realisation that Jesus' return from the grave meant that he had conquered death. The dispensation of the tyranny of Satan will make place for the dispensation of God's kingdom. Therefore Jesus adds in verse 22: 'No one will take away your joy.'

After his crucifixion the sinful world will rejoice, says Jesus in verse 20, thinking that in the death of Jesus God's Kingdom has been crushed. However, when Jesus rises from death, the outcome of events will be the direct opposite: it will prove that it is the power of Satan and his followers, even the power of death that has been crushed by Jesus, the triumphant Christ (cf. Coetzee 1995:18). Then the disciples will rejoice because they will see Jesus as the kóproৎ of the kingdom. This perspective adds a new dimension to words of verse 22: 'No one will take away your joy.'

9.The idea of Käsemann that these words of Jesus form part of a Johannine "naive docetism' of physical disappearance and reappearance of Jesus, is discussed and refuted by Hanson (2006:275-276).
At this point we need to return to John 14:28. Thus far we have seen that John 16:22 speaks of the joy of seeing Jesus after his resurrection. In 14:28, however, the disciples' joy is connected to Jesus' ascension: They should be joyful because he is going to the Father. But even in John 16:22 the joy regarding the ascended Jesus is not entirely out of the picture. The fact that Jesus is going to the Father is mentioned in 16:17 and again in 16:18. This makes perfect sense considering the unbreakable link between Jesus' resurrection and his ascension. Only at his ascension his resurrection was declared as mission accomplished. Thus the joy of the disciples seeing Jesus again in John 14:28 and 16:22 is connected to both his resurrection and his ascension.

In this regard it is important to note a slight yet significant change in subject between verses 19 and 22. In verse 19 Jesus spoke of the disciples who will see him ('you will see me';

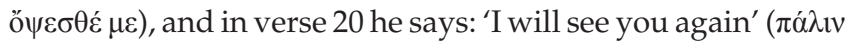

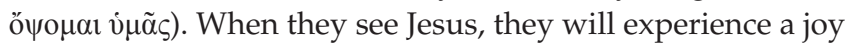
that no one can take from them. But when he sees them again, they will have access to the Father in Jesus' name (cf. Neyrey 2007:272). He will then be in a position to speak as their intercessor before the Father, which is after his ascension.

Another connection between Jesus' resurrection and his ascension comes forward in the fact that directly after John 16:22 the theme of prayer is introduced (16:23-27). In verses 23-24 Jesus says: 'Until now you have not asked for anything in my name, but in that day the Father will give you whatever you ask in my name.' 'That day', is referring to the day of Jesus' ascension; he will be with the Father so that henceforth he can intercede for us (Ridderbos 1987:194). Yet his intercession at the right hand of the Father is based on Jesus' redemptive work on the cross and his victorious resurrection.

Accordingly 'that day' in verse 23 refers to the new dispensation that was brought about by Jesus' resurrection and ascension. From 'that day' onward believers can ask anything from God in the name of Jesus. This is so because his death and resurrection provide the basis, the legal ground, for the hearing of their prayers; and being at the right hand of God Jesus has the platform from which he can intercede for all prayers. Therefore Jesus says in verse 24: 'Ask and you will receive, so that your joy will be complete' (cf. also 3:29 and 15:11). To the disciples, access to the Father in the name of the risen and ascended Jesus 'was part of the joy which was promised in [the] place of their present sorrow; or would, indeed, bring that joy to completion' (Bruce 1992:323).

In summary: In John16:20-24 Jesus speaks of the joy his disciples will receive when they see him as the risen Lord. The joy would be special because they will see him as the Lord who has conquered death and thereby has made God's kingdom to break through into this world. Their cup of joy

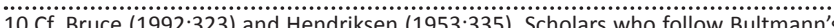
idea of realised eschatology prefer to understand these verses not in terms of jea of realised eschatology prefer to understand these verses not in terms of
Jesus' ascension but only of his resurrection. Keener (2003:1047), for example says: 'Jesus returns in the resurrection to impart eschatological life through the
spent. says: 'Jesus
Spirit.' 
would be even more overflowing since after his ascension they will have Jesus as the legal basis for their prayers to be heard by the Father.

\section{John 17:13}

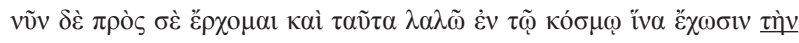

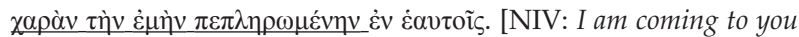
now, but I say these things whilst I am still in the world, so that they may have the full measure of my joy within them.]

This passage differs from all the preceding, because here Jesus is not speaking to his disciples but to his Father in prayer. Yet in verse 13 he is still speaking of his disciples' joy. Most commentators take the verse to say that although Jesus

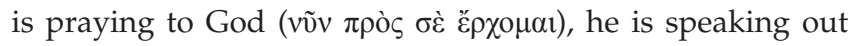

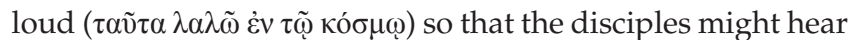
that he intercedes for them, and in hearing might rejoice. ${ }^{11}$ It is important to note that Jesus in John 17:13 already acts as intercessor for his disciples by the Father. In John 16:23-24 he promised his disciples that their joy will be complete in that day when he, as risen and ascended Lord, will intercede for them at the Father (cf. the section 'John 16:20-24' above). In chapter 17, almost as a preview of that day, he intercedes for them. And to see and hear him praying for them to the Father arouses complete joy in the disciples.

As in John 15:11 Jesus now also speaks of 'his own joy that will be fulfilled in them'. Carson (1991:564) is convinced that Jesus thereby refers to his own joy flowing from a life of obedience before the Father. This time Jesus, having been completely obedient to the very end, is on the verge of being the perfect intercessor for his disciples. By having Jesus as perfect intercessor before God, the disciples receive the joy of Jesus in full measure.

Therefore it seems that John 17:13 speaks of the complete joy of the disciples because they encountered Jesus as their intercessor by the Father.

\section{John 20:20}

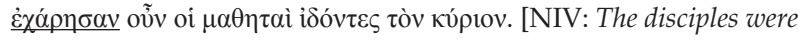
overjoyed when they saw the Lord.]

The final reference to joy in John brings the theme to its climax. The disciples finally saw the risen Lord standing before them in person. He had endured the cross, as proved by the marks in his hands and the wound in his side. And he had conquered death by rising bodily from the tomb, for he was present not only in spirit but also in body. Yet Jesus did not return merely to his earthly existence. He was standing before them in glory, ready to return to the Father. That is how the disciples saw him. No longer did they see Jesus

11.For eample Bernard (1948:572); Carson (1991:264); Ridderbos (1987:210). Keene (2003:1059) suggests that $\tau \alpha \tilde{v} \tau \alpha \lambda \alpha \lambda \tilde{\omega}$ refers to the entire teaching of Jesus in the Gospel. However, in 'John 15:11' above, it has been pointed out that $\tau \alpha v \tau \tau$ almost always refers to what has been said in the previous sentences. standing before them, but for the first time in the Gospel one hears that they saw the Lord (Ridderbos 1987:311).

Seeing the Lord, the disciples rejoiced. The verb used here is a simple aorist indicative, $\dot{\varepsilon} \chi \alpha \dot{\rho} \eta \sigma \alpha v$. Here is no intensive

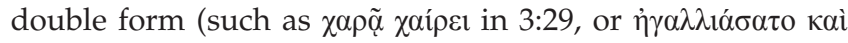

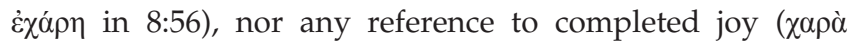
$\pi \varepsilon \pi \lambda \eta \rho \omega \mu \varepsilon ́ v \eta$, as in 3:29, 15:11, 16:24 and 17:13). Nevertheless, the immediate context provides the emphasis. The disciples were looking at the risen Lord who had accomplished everything that he had promised them during his earthly ministry. Their joy was now a joy completed. Therefore most commentators (e.g. Brown 1966:1035; Bultmann 1971:692; Keener 2003:120; Ridderbos 1987:3113) agree that the joy of the disciples in John 20:20 is to be understood as the fulfilment of Jesus' promise at his farewell discourse (16:20-24): 'Your joy will be complete.'

Probably it can be taken one step further. The joy of the disciples in John 20:20 is the fulfilment not only of the zapò $\pi \varepsilon \pi \lambda \eta \rho \omega \mu \varepsilon \dot{v} \eta$ promise of John 16:20-24, but also of all the other promises of complete joy in the Gospel. John 20:20 is the point where all the preceding joy references of the Gospel finally meet. This will be discussed in the following section.

\section{Style and structure of the fourth gospel}

Unique to the structure of the fourth Gospel is that thoughts and concepts are often repeated and developed. Characteristic of this structure is a progressive line of development that takes on a more or less spiral-like pattern (Van der Watt 2007:26). At every repetition of the specific thought or concept the author takes it to a following level, building up to a climax (cf. Du Rand 1990:4).

For the purpose of this article it is our task to ascertain whether John's repeated reference to joy also fits into this spiral pattern. Thus joy would prove to be a distinct Johannine theme. For this purpose it is necessary to recapitulate the central argument about joy as formulated in the discussion of the respective passages above. In doing so, it seems that more than one developing line can be seen in the above discussions:

- First a temporal progress can be noted. This is evident in the first four joy passages:

John 3:29 starts with John the Baptist, the preparer of the way, who stood on the threshold of the New Testament and rejoiced in seeing the Christ come into the world.

John 8:56 goes back in time to Abraham, who stood at the beginning of God's covenantal promises and rejoiced in seeing Christ from afar in faith.

John 4:36 and 11:15 proceed to the time of the Christ in the world, when the disciples, as New-Testament eyewitnesses saw the first fruits of his preaching - by word and by deed - and rejoiced at the realisation that in him the Messianic age had indeed arrived. 
All the remaining joy passages are focused on the last phase of Jesus' dwelling with his disciples on earth, and mostly contain his words to them during his farewell discourse. In these passages the spiral-development is not as much temporal as it is a revelation-historical progress. At every repetition the focus shifts to a joy about a following phase of Jesus' messianic task.

It begins with the joy of the disciples about their union with Christ, and the fact that his loving obedience to the Father that can be seen in their lives too. This aspect of joy is emphasised by Jesus in the vine-and-branches metaphor in John 15:11:

- The next phase is the joy that the disciples can expect after Jesus' resurrection, because they will then see him as the Lord who has conquered death and who is going to the Father in the heavenly glory of his kingdom. This aspect of joy is presented in 14:28 and explained in John 16:20-24 by the image of the child-bearing woman.

- Thereupon the disciples will be overjoyed to know that, once at the right hand of the Father, Jesus will intercede for them and all believers. This aspect of joy comes forward in John 17:13 where Jesus, however still on this earth, already intercedes for them at the Father.

- Finally all of the above aspects of joy come together in John 20:20 where the disciples were overjoyed when they saw Jesus as the risen Lord. The joy of Abraham looking forward to the coming Messiah, the joy of the Baptist who saw the promised Messiah appearing in the flesh, the joy of the disciples who witnessed his words and deeds, their joy every time they saw in their lives that they were indeed one with him, their joy of expecting him to conquer death, to go to the Father from where he will intercede for them and from where he will rule as King - all of this became complete in their joy when they finally saw Jesus as the risen Lord standing before them.

\section{Joy a developed theme in John}

Up to this point it has become clear that the concept of joy is introduced in John in a definite developing manner. It is not the what of the joy that is developed as much as the who and the why. At first it seems that the author's focus is on the persons who rejoice, but gradually it becomes clear that in each case the important matter is the reason for joy. Basically the reason why each person rejoices is that they see (or hear) Jesus:

- In John 3:29 the Baptist's joy is fulfilled because he saw the Christ arrive.

- In John 4:36 the disciples rejoiced because they saw the first fruits of Jesus' preaching in this world, realising that in him the Messianic age had indeed arrived.

- In 8:56 the joy of Abraham springs from the fact that he could prophetically see the day when the promised Christ would come into this world.

- In John 11:15 Jesus rejoices because he knew that the disciples will be eyewitnesses of the sign of Lazarus being raised from the dead.
- In 15:11 Jesus teaches that the disciples will receive joy when they experience (see) the fruit of obedience to the Father coming from their union with Christ.

- In John 14:28 and 16:20-24 Jesus comforts his disciples by saying that their joy will be complete when they will see him as the risen Lord who is going to the Father.

- In John 17:13 the disciples' joy comes from hearing (and seeing) Jesus interceding for them before the Father.

- Finally, after Jesus' resurrection, the disciples rejoiced because they now indeed saw him as the risen Lord.

\section{Joy in a broad theological framework}

All of the preceding explanation prove that there is enough reason to view joy in the fourth Gospel as a typical Johannine theme. As indicated above, this theme is developed in a more or less temporal line. But in our discussions also another level of development gradually came forward, namely it is developed within a broad theological framework of the entire Bible. This development can be summarised as follows.

Firstly it is developed within the framework of the covenant of the Lord, with its joy-giving promise of the coming Messiah. Already in the Old Testament Abraham rejoiced in this expectation (John 8:56). Eventually the Baptist, who according to God's covenantal promise was the preparer of the way (cf. Ml 3:1; 4:5), rejoiced when the promise became true (3:29). The words Jesus spoke and the signs he performed brought joy to the disciples $(4: 36 ; 11: 15)$ for they could see that the Immanuel promise had become true: in Jesus the Lord is dwelling amongst the people (cf. Ezk 43:7). Also Jesus' vineand-branches metaphor portrayed to the disciples that God is not only amongst them but also in them, united with them through the Spirit (15:11). Thus God brings about obedience which is the demand and the promise of his covenant (cf. Jr 31:31-33). Finally Jesus' death and resurrection whereby he paid for all our sins was the fulfilment of God's covenant of grace (cf. Is 40:1, 2).

Secondly the theme of joy in John is connected with the topic of God's kingdom. Although the kingdom of God is mentioned only in John 3:3, 5 it does not mean it is absent from the Gospel. It is only referred to in different terms.

As Childs (1993:644) points out, the sending of the Son from heaven by the Father (e.g. 7:29, 33) is in fact a reference to the coming of God's kingdom. In John 4:36 the theme of joy is implicitly linked to the sending of the Son by the Father, where Jesus by means of a metaphor ('the sower will rejoice with the reaper') in a subtle reference to Amos 9:11 teaches his disciples that he has been sent to restore the fallen house of David (cf. 'John 4:36' above), that is sent to bring about the kingdom of God.

As indicated by Coetzee (1990:44), 'eternal life' in the fourth Gospel is frequently analogous to 'the kingdom of God'. Therefore Jesus' explanation in John 4:36 that the harvest 
'brings a crop of eternal life' is a confirmation that he is speaking of God's kingdom.

Brown (1984:87) points out that in the fourth Gospel the kingdom is sometimes implied also by Jesus' 'I am'-sayings. This is especially true of 'I am the resurrection and life' (11:25), spoken by Jesus just before he raised Lazarus from the dead. This 'I am'-saying is also linked to the joy passage in John 11:15.

Most of the 'joy' passages in John are somehow related to the topic of God's kingdom. The disciples should have abundant joy because in the harvest amongst the Samaritans they could see that the Son of God has come to establish his kingdom of eternal life. Likewise Lazarus being raised from the dead proved that the Son of God has power and authority even over death. And when Jesus himself eventually rose from the death, his power as Son of God and King of all was revealed.

The link between joy and kingdom is continued in John 14:28, 16:20-24, 17:13 and 20:20. All of these passages deal with the joy of the disciples because Jesus is about to conquer death (16:20-24) and return to them as the risen Lord (20:20) before he will take up his throne with the Father in glory (14:28; cf. Childs 1993:644).

\section{Conclusion}

From the above investigation it proves that joy can indeed be regarded as a specific theme that is developed in the fourth Gospel. It is developed along what can be called a temporal and a (revelation-) historical line, which starts with the joy of Abraham prophetically seeing the coming Christ ahead of time, continues with the joy of John the Baptist, who saw the Christ in the fullness of time. From there it expands to the joy of the disciples in the presence of Jesus on earth (before his death), their joy when seeing him as risen Lord (after his resurrection) and their joy in hearing him intercede for them at the Father (a preview of Christ after his ascension).

The final conclusion of the article is that in the fourth Gospel joy is presented as an aspect of faith that is rooted in Jesus Christ himself, especially in seeing him as the promised Messiah. The joy of seeing Christ can be linked to John's repeated reference to 'seeing' (e.g. 1:14, 18, 51; 20:29). However, references to 'seeing' as possible theme or motif in the fourth Gospel calls for a new investigation.

\section{Acknowledgements Competing interests}

The author declares that he has no financial or personal relationship(s) that may have inappropriately influenced him in writing this article.

\section{Reference}

Abbott, H.P., 2002, The Cambridge introduction to narrative, Cambridge University Press, Cambridge.

Balla, P., 1997, Challenges to New Testament theology, Mohr Siebeck, Tübingen.

Barrett, C.K., 1955, The Gospel according to St. John, SPCK, London.

Bernard, J.H., 1948, A critical and exegetical commentary on the Gospel according to St. John, Clark, Edinburgh.

Bouma, C., 1974, Het Evangelie naar Johannes, Kok, Kampen.

Brodie, T.L., 1997, The Gospel according to John: A literary and theological commentary, Oxford University Press, Oxford.

Brown, R.E., 1966, The Gospel according to John (i-xii), Doubleday, New York.

Brown, R.E., 1984, The churches the apostles left behind, Geoffrey Chapman, London. Bruce, F.F., 1992, The Gospel of John: Introduction, exposition and notes, Eerdmans, Grand Rapids.

Bultmann, R., 1971, The Gospel of John: A commentary, Blackwell, Oxford.

Carson, D.A., 1991, The Gospel according to John, Eerdmans, Grand Rapids.

Childs, B.S., 1993, Biblical theology of the old and New Testaments, Fortress, Minneapolis.

Coetzee, J.C., 1990, 'Die teologie van die Johannesevangelie', in A.B. du Toit (red.), Handleiding by die Nuwe Testament, deel 6, pp. 37-72, NG Kerkboekhandel, Pretoria.

Coetzee, J.C., 1995, Keys to God's revelation in the New Testament, EFJS, Orkney.

De Lange, T., 2008, Abraham in John 8, 31-59: His significance in the conflict between Johannine Christianity \& its Jewish environment, Amphora, Amsterdam.

Du Rand, J.A., 1990, 'Inleiding tot die Johannesevangelie', in A.B. du Toit (red.), Handleiding by die Nuwe Testament, deel 6, pp. 1-36, NG Kerkboekhandel, Pretoria.

Du Rand, J.A., 2005, 'The creation motif in the fourth Gospel: Perspectives on its narratological function within a Judaistic background', in G. van Belle, J.G. van der Watt \& P. Maritz (eds.), Theology and Christology in the fourth Gospel, pp. 1-28, Peeters, Leuven.

Freedman, W., 1971, 'The literary motif: A definition and evaluation', Novel: Forum on Fiction 4(2), 123-131. http://dx.doi.org/10.2307/1345147

Gulin, E.G., 1936, Die Freude in Neuen Testament, 2. Teil, Das Johannesevangelium, Finnischen Literatur-Gesellschaft, Helsinki.

Haenchen, E., 1980, Das Johannesevangelium: Ein Kommentar, Mohr Siebeck, Tübingen.

Hanson, A.T., 2006, The prophetic Gospel: A study of John and the Old Testament. Clark, London.

Hendriksen, W., 1953, New Testament commentary: Exposition of the Gospel according to John, Baker, Grand Rapids.

Holwerda, D.E., 1959, The Holy Spirit and eschatology in the Gospel of John, Kok, Kampen.

Hunter, A.M., 1965, The Gospel according to John, Cambridge University Press, Cambridge.

Just, F., 2012, 'Joy in the fourth Gospel: Introductory materials for the fourth Gospel, overviews, comparative charts, and other study aides', in The Johannine literature web, viewed 17 May 2015, from http//catholic-resources.org/John/Intro.html

Keenan, T.L., 1963, 'The Johannine concept of joy', M.A. thesis, Faculty of Theology, Catholic University.

Keener, C.S., 2003, The Gospel of John: A commentary, Hendrickson, Massachusetts.

King, P.J. \& Stager, L.E., 2001, Life in biblical Israel, Westminster John Knox, Louisville.

Köstenberger, A.J., 2002, Encountering John: The Gospel in historical, literary, and theological perspective, Baker, Grand Rapids.

Lincoln, A.T., 2000, Truth on trial: The lawsuit motif in the fourth Gospel, Hendrickson, Massachusetts.

Louw, J.P. \& Nida, E.A., 1988, Greek-English Lexicon of the New Testament, based on semantic domains, United Bible Societies, New York.

Neyrey, J.H., 2007, The Gospel of John, Cambridge University Press, New York.

Ridderbos, H.N., 1987, Het Evangelie naar Johannes, Kok, Kampen.

Sanders, J.N., 1968, A commentary on the Gospel according to St. John, Black, London.

Schwank, B., 1998, Evangelium nach Johannes, Eos, St Otillien.

Van der Watt, J.G., 2000, Family of the king: Dynamics of metaphor in the Gospel according to John, Brill, Leiden.

Van der Watt, J.G., 2007, An introduction to the Johannine Gospel and letters, Clark, London.

Wallace, R.S., 2004, The Gospel of John: Pastoral and theological studies, Rutherford Edinburgh. 